\title{
Language and Loyalty: Governor Harding and Iowa's Danish-Americans During World War I*
}

Peter L. Petersen

FEW IOWA POLITICANS have been involved in more controversies during their public careers than William Lloyd Harding, who has the unhappy distinction of being the state's only governor to have impeachment proceedings initiated against him. Rising rapidly in Republican party ranks following his election to the Iowa House of Representatives fromWoodbury County in 1906, Harding served two terms as Lieutenant Governor before winning the bitterly divisive 1916 Republican gubernatorial primary. He then went on to defeat Democrat Edwin T. Meredith in one of the most acrid campaigns in Iowa history. Hence, by the time he entered the governor's office in 1917, Harding had aroused the anger of several significant forces in Iowa politics. His alleged "moistness" on the issue of prohibition had infuriated many drys while his stand with farmers opposed to paved roads had earned him the antipathy of the good roads people. In addition, he had become embroiled in a personal feud with Gardner Cowles, publisher of the Des Moines Register, and thus could expect continued criticism from one of the state's leading newspapers.

As governor, Harding hoped to rise above the contentiousness which had accompanied so many of his earlier activities. But there was no escape for him. A few months after he took office, the United States entered World War I and his actions as wartime governor quickly earned him additional enemies. Ultimately,

*A grant from the West Texas State University Committee on Organized Research supported portions of the research for this article.

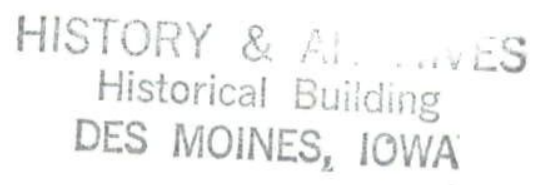


anti-Harding forces in the legislature marshalled sufficient strength and on April 11, 1919, the members of the House Judiciary Committee of the Thirty-Eighth General Assembly voted to begin impeachment proceedings. After one day of debate, the full House membership chose to drop the action and passed instead a resolution of censure. Nevertheless, Harding's political career was ruined. In the words of his biographer, "he was literally cashiered from the party of the state he had served and loved."

Certainly the most controversial of all Harding's wartime actions was his decision to ban the public use of foreign languages. From the beginning of American involvement, Harding and many other state leaders had expressed concern over what they considered to be an absence of patriotism among Iowa's foreign-born. Numerous people joined the governor in blaming "foreign elements" for the failure of the first statewide liberty bond drive in 1917. In September of that year, Harding took the lead in organizing a program to "Americanize" Iowa's population. The state performance during subsequent bond drives did show striking improvement, but the effort to stimulate patriotism contributed to several incidents involving those of foreign descent. There were reports of barns and other farm buildings being painted yellow, anonymous letters, threats, and other equally disturbing activities. $^{2}$

Although Harding dismissed these episodes of harassment as "petty differences," he was obviously bothered by them; and on May 23, 1918, he issued the following proclamation:

FIRST. English should and must be the only medium of instruction in pubic, private, denominational or other similar schools.

SECOND. Conversation in public places, on trains and over the telephone should be in the English language.

THIRD. All public addresses should be in the English language.

'John E. Visser, "William Lloyd Harding and the Republican Party in Iowa, 1906-1920" (unpublished Ph.D. thesis, University of Iowa, 1957), p. 10. The impeachment proceedings revolved around charges that Harding had improperly granted a pardon to a convicted rapist. Lurking just below the surface, however, were other issues and the pardon case served as a rallying cry for those with grievances accumulated throughout Harding's stormy public career.

${ }^{2}$ Ibid., pp. 230-235. 
FOURTH. Let those who can not speak or understand the English language conduct their religious worship in their homes.

The governor believed his action would remove the major source or irritation existing between the state's old stock and foreignborn citizens. The use of a language other than English during a period of war, the governor explained, had an unfortunate tendency "to create discord among neighbors and citizens." Consequently, abolition of the practice would reduce tension and allow the people of Iowa, "united as one people with one purpose and one language, [to] fight shoulder to shoulder for the good of mankind., ${ }^{3}$

It soon became apparent that not all Iowans agreed with their governor. While most residents of the state did not object to the prohibition of German, "the language of the enemy," many thought that by banning all foreign languages, Harding was being overzealous. The Des Moines Register labeled the proclamation a "needless interference" with the worship, public meetings and daily intercourse of "hundreds of thousands of good people in the state." Pointing to mounting criticsm of Harding's order, the newspaper called upon him to "swallow whatever feeling of personal pride he may have on the matter and frankly admit that the order was ill-considered and withdraw it at once." ${ }^{4}$ Harding, as everyone expected, chose to ignore the Register's advice and continued to defend his proclamation. He was unable, however, to still criticism of it. Bohemians from Cedar Rapids made strenuous protests ${ }^{5}$ as did many Norwegians, Swedes, and Dutch from across the state. The Danes, however, were particularly offended by the proclamation.

The Danish contingent in Iowa's foreign-born population was not large - the 1915 census listing only 18,905 Danish-born residents in the entire state ${ }^{6}$ - but a combination of factors served to

${ }^{3}$ William Lloyd Harding, "Iowa War Proclamations," Iowa and the War. No. 13 (July, 1918), pp. 43-47.

${ }^{4}$ The Des Moines Register, June 1, 1918. Just how many Iowans relied upon a foreign language in 1918 is impossible to determine. Although the 1915 census put Iowa's foreign-born population to $264,169(11.2 \%)$ the Register's claim that the language proclamation interfered with the activities of "hundreds of thousands" was clearly an exaggeration.

${ }^{5}$ Cedar Rapids Gazette, May 27, 1918.

${ }^{\circ}$ Census of Iowa for the Year 1915, p. 462. 
make the Danes uniquely sensitive to the prohibition of languages other than English. For one thing, their habit of congregating in or around certain communities provided little incentive for learning English. Describing the town of Elk Horn in southeastern Shelby County in 1889, Kristian Anker, a local Lutheran minister, reported: "Visitors often say Elk Horn is a little Denmark. . . . One may live for months in Elk Horn without needing to use any language other then Danish." While conceding that children were learning some English, Anker asserted that "if the Danish school and church do their work, I can not conceive of the time when Danish will not be the community language (hverdagsspoget) in Elk Horn."7 Elk Horn, with its folk high school, college, and orphanage, was the largest and most famous Danish settlement in Iowa, if not the entire United States. But several towns including Kimballton in neighboring Audubon County, Ringsted in Emmet County, and Fredsville in Grundy County, were often called "little Denmarks," too ${ }^{8}$ further indicating the tendency of Danes to segregate themselves from other ethnic stocks. In fact, well over one fourth of Iowa's Danish population lived in three southwestern counties-Audubon, Pottawattamie, and Shelby. ${ }^{9}$

Some Danes clung to their language for religious reasons. Many, though certainly not all, were Lutherans, and as late as World War I a substantial majority of the pastors in the DanishLutheran Churches in Iowa had been born in Denmark. Even native-born ministers were expected to preach in Danish. In 1918, the Theological Department of Grand View College in Des Moines, and Trinity Theological Seminary at Blair, Nebraska, the two major sources of clergy for the Danish-Lutheran Churches, were still conducting all their theological training in Danish. For many older Danes, the thought of church services in

${ }^{7}$ Kristian Anker in Meddelelser fra den dansk-amerikanske Mission [Reports from the Danish-American Mission], (Odense, Denmark, 1872-1894), Vol. III, pp. 268-273, quoted in Thomas Peter Christensen, A History of the Danes in Iowa (Solvang, California, 1952), pp. 85-86.

${ }^{8}$ T. P. Christensen, A History of the Danes in Iowa, pp. 89-94; George T. Flom, "The Danish Contingent in the Population of Early Iowa," Iowa Journal of History, IV (April, 1906), 220-244. Elk Horn and Kimballton continue to emphasize their "Danishness." See Beverly Larson, "Danish Heritage," The Iowan, 18 (Summer, 1970), 10-13, 53.

${ }^{\circ}$ Census of Iowa for the Year 1915, pp. 462-464. 


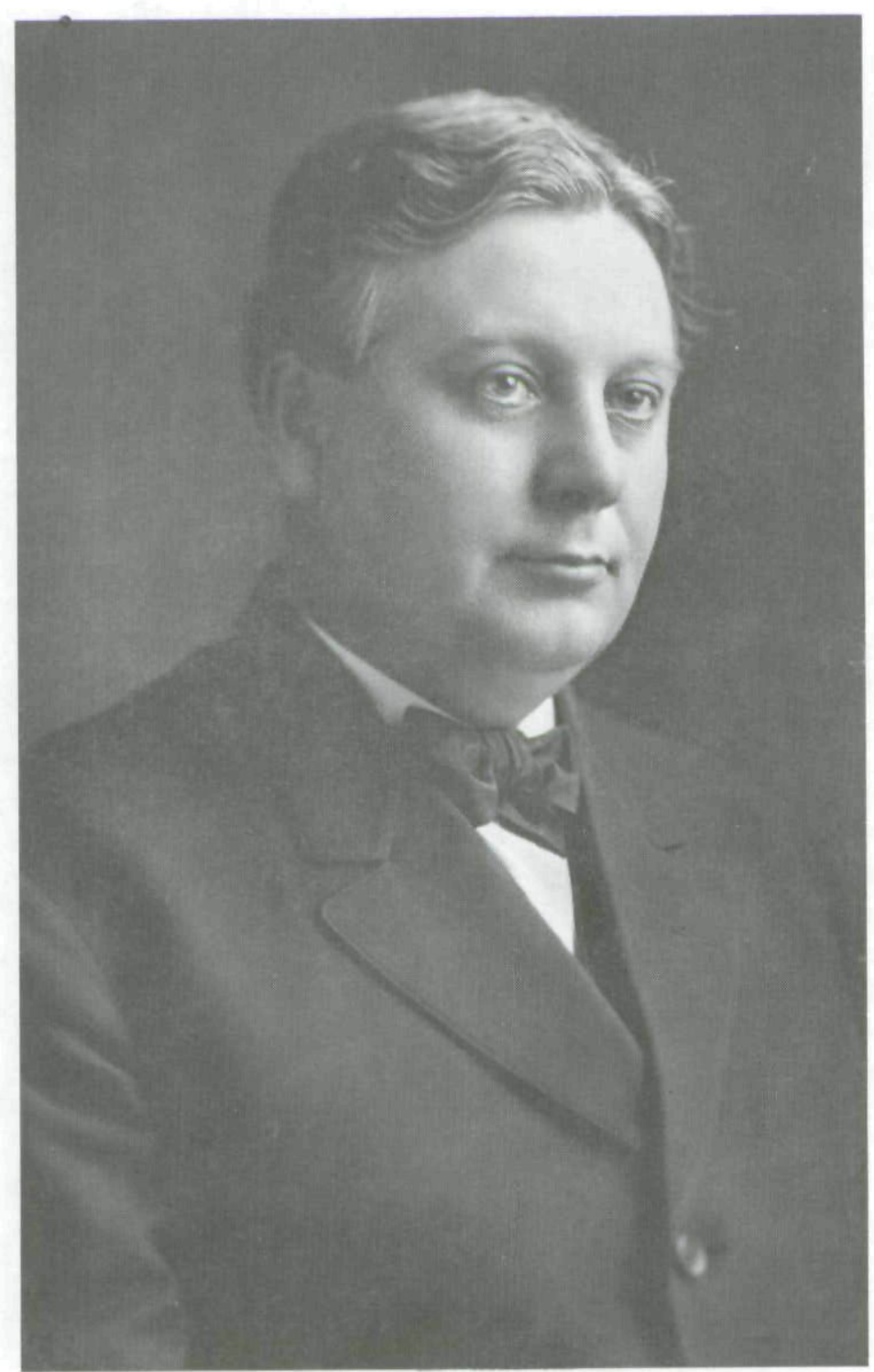

Courtesy of State Historical Department. Historical Museum and Archives Division

William L. Harding 
"the American language" was almost unbearable. Not a few of this generation believed that the Bible had been written in Danish and that God had a preference for prayers in that language. When suggestions about using English came up at church meetings, many of the elders nodded disapprovingly and muttered about "den Engelske Syge"- the English disease. ${ }^{10}$

Deeply ingrained in Danish history was another factor that affected the language habits of Danish immigrants. Denmark had suffered greatly as the result of European wars in the 19th Century. At the Congress of Vienna she had been forced to give Norway to Sweden. Then in 1864, after an invasion by troops from Prussia and Austria, she had forfeited the duchies of Slesvig and Holstein. As a consequence of these disastrous wars, Denmark lost about a third of her territory and was shunken to her smallest size since the establishment of the kingdom centuries before. It was the loss of Slesvig, particularly north Slesvig with its heavily Danish population, "that the Danes grieved over and bitterly deplored," writes Thomas Peter Christensen. "It did much to produce in the whole Danish people a conquered-people's psychology and a fear of national extermination. . . ." Mixed with this fear was a feeling of sorrow as Danes watched Prussia's efforts to "Germanize" the Danish population of Slesvig after 1864. Prussian officials forbade the use of Danish language in schools, churches, courts and ultimately at all public gatherings. They also banned Danish costumes, plays, songs, and lectures. ${ }^{12}$ It should be no surprise, therefore, that many Danes in Iowa, some of them refugees from Prussian oppression in Slesvig, had little love for language proclamations.

Nor is it surprising that Danes in the United States supported the American declaration of war against Germany in 1917 with considerable enthusiasm. In a recent history of Elk Horn there is a picture of Rasmus Hansen, a veteran of the 1864 Danish war

${ }^{10} \mathrm{~T}$. P. Christensen, A History of the Danes in Iowa, pp. 122-123; William E. Christensen, Saga of the Tower: A History of Dana College and Trinity Seminary (Blair, Nebraska, 1959), pp. 124-127.

"T. P. Christensen, A History of Danes in Iowa, p. 13; W. Glyn Jones, Denmark, (New York, 1970), pp. 56-57.

${ }^{12}$ Stanley M. Toyne, The Scandinavians in History (London, 1948), pp. 266267; William L. Shirer, The Challenge of Scandinavia (Boston, 1955), pp. 218 . 220 . 
against Prussia, grasping the hand of his son Alfred as the latter prepared to leave for military service. A large American flag is prominent in the background. Nine other Danish-American youths had joined young Alfred in enlisting during the first weeks of the war. Their departure on April 21, 1917, had been the occasion for several demonstrations in Elk Horn and Kimballton. One observer reported "the 'Star Spangled Banner' was heard often that night and each time it brought the Danes, young and old, to their feet cheering." Residents of Elk Horn, furthermore, had voted on August 2, 1917, to build a public high school to replace their Danish folk high school. ${ }^{13}$ Consequently, Iowa's Danish population believed that it had acted responsibly in the months before May, 1918.'

For a variety of reasons, then, Danes in Iowa deeply resented Harding's language proclamation. Yet their initial response to it was cautious and conciliatory. They did not wish to appear unpatriotic or to hinder the war effort. Perhaps a writer to the Des Moines Register described the situation best. Explaining that he had lived among Danes for five years and could vouch for their loyalty, F. M. McClintock wrote from Chapin: "Representative citizens of this community have expressed their willingness to cooperate in bringing about a general substitution of English for their native tongue in religious services, but they regret exceedingly the abruptness and apparent harshness of the governor's order." 14

This is how matters stood until July 4, when Harding delivered an Independence Day message on the subject of language and loyalty. Speaking before a crowd of nearly 2,500 at Sac City, the governor lashed out at those who had criticized his proclamation. According to the Sac Sun, the governor cited the Danish settlements in Shelby and Audubon Counties as examples of what he was trying to correct. Noting the widespread use of Danish in the area, especially in the schools and churches, he insisted that the young people of those communities were not getting a proper American upbringing. "When they get through," he reportedly said, "they are full grown, 100 per cent Dane." Harding did not stop here. He went on to deprecate the Danish contribution in

${ }^{13}$ Burt Wittrup (ed.), Elk Horn's First 50 Years (Elk Horn, 1966), p. 15.

${ }^{14} \mathrm{~F}$. M. McClintock to the Editor, Des Moines Register, July 6, 1918. 
Iowa and then, once more according to the Sac Sun, he said: "Now, think of a man who was brought from the filth of Denmark and placed on a farm for which he has paid perhaps $\$ 3$ an acre. Ye gods and fishes, what Iowa has done for him he never can repay." 15

The Des Moines Register, Harding's old nemesis, was not about to let the Sac City speech pass without comment. On July 19 , in a lengthy editorial entitled "Harding at Sac City," the newspaper bitterly scored the governor's address, calling it a part of a "know-nothing campaign against the people of foreign birth. ..." The Register reported that a survey of the latest "contingent sent to Camp Dodge from Audubon county" revealed a high percentage of young men with Scandinavian names, and asked why the governor, who was "of enlistment age" and was in splendid physical condition, had not offered to go? The Register charged that everyone knew that Denmark-a dairying nation-was a "model for cleaniness and neatness," and reminded the governor that many Iowa Danes had fled "Prussian tyranny" in Slesvig. Three days later, the newspaper returned to the attack, this time reporting that of the 163 men recently drawn in Audubon County for the draft, "there are 99 of Danish parentage . . . to 64 of all other parentage." 16

The obvious intent behind the Register's editorals was to embarrass Governor Harding by further inflaming the language controversy. And as expected, when Danes read the accounts of what Harding had allegedly said about them at Sac City, their wrath knew few bounds. Letters critical of Harding poured into the Register and Dannevirke - the Danish language newspaper published at Cedar Falls. Some writers saw a similarity between the Iowa governor and the hated German Kaiser, while others assailed Harding's ignorance of Danish habits and customs. ${ }^{17}$

Perhaps the most significant letter came from the pen of Peder Sorensen Vig. Born and educated in Denmark, Vig had emigrated to the United States following his ordination as a Lutheran pastor. For nearly forty years Vig had ministered among

${ }^{15}$ Sac Sun, July 11, 1918.

${ }^{10}$ Des Moines Register, July 19; July 22, 1918.

${ }^{17}$ Ibid., July 27; July 31; August 2, 1918; Dannevirke, July 24; August 14; August 28, 1918. 
Danish immigrants in Iowa, Nebraska, and Wisconsin. Famous both as a Biblical scholar and a historian, he had taught at Elk Horn College before moving to Blair, Nebraska, in 1897, to become President of Trinity Seminary. His contributions to the two volume work, Danske i Amerika (Danes in America), had earned him a reputation as a leading authority on Danish-Americans, while others viewed him as one of the greatest living DanishAmerican Lutheran theologians. ${ }^{18}$ And since he may be considered as the spokesman for many of Iowa's Danes, his response to Harding is of special importance.

First explaining that he had taken out citizenship papers in Shelby County in 1894, Vig wrote that he had since "tried to be true to the oath of allegiance to the United States" and he had not "the faintest idea that the use of the Danish language, in public or in private, was contrary to that oath and to true citizenship. . . ." Nor did he believe so now. "Patriotism and loyalty are not matters of the lip," he insisted, "but of the heart, otherwise a parrot might be patriotic, and stammerer dying for his country a filthy slacker only, according to the logic of fanaticism." Vig accused Harding of having a "very superficial" acquaintance with "the Danish-born inhabitants of the state." The governor, Vig said,

knows that there are Danes in Iowa, that they speak Danish and are not ashamed of it, which certainly is true. And why should they be? It is no fault of theirs that they were born in Denmark. . . . A person may be born Denmark and still be a good American citizen, and a dog may be born in America and still be a dog. No language in itself is either loyal or disloyal, but it is the use made of such languages that counts. ${ }^{19}$

As the outcries against the Sac City speech continued, one of Harding's long-time political and personal friends, Thomas $\mathrm{H}$. Smith, wrote from Harlan, the county-seat of Shelby County, that he found Danes in the community at a "white heat" over the matter. Smith explained that he had originally

thought the disloyalty charge hurt the worst but I find the statement 'coming from the filth of Denmark' is the unpardonable sin. The charge that they are ' 100 per cent Danes' is not taken so much as a charge of disloyalty as that they are Danish in manners and customs etc. This they resent but not with the feeling they do of being filthy.

${ }^{18}$ W. E. Christensen, Saga of the Tower, pp. 50-53; Ed. S. White, "Elk Horn College," Midland Monthly, II (December, 1894), 461-462.

${ }^{19}$ Peder Sorensen Vig to the Editor, Des Moines Register, July 31, 1918. 
It was his belief, Smith told Harding's secretary, that the governor should quickly issue a communication that would "clear the atmosphere and put myself and his other friends here in a position to come to his aid." ${ }^{20}$

Accordingly, on August 12, Harding sent Smith a lengthy letter intended for public release. "I wish to say," he wrote,

that $\mathrm{I}$ deny most emphatically that in my address at Sac City on July Fourth, or any other address delivered by me, I said any unkind thing, or made any derogatory remarks about the cleanliness, respectability, high ideals, or patriotism of Denmark, Danes in general, Danes in Shelby or Audubon county, or any individual Dane.

Harding submitted to Smith that the report labelling his remarks about Danes derogatory had first appeared as an editorial in the Des Moines Register. "Coming from this source," the governor insisted, "you will need to discount the story about ninety per cent." (Harding, of course, was ignoring the fact that the report of the speech first appeared in the Sac Sun.) The governor continued by saying that he had had many contacts with people of Danish descent and "the memory of my association and acquaintance with each is pleasant." Nor, he said, was the word "filth" a part of his vocabulary. Harding then offered Smith a synopsis of his talk at Sac City. "I was speaking about the war in which we are now engaged," the governor recalled.

I said, "Germany wanted the United States of America in this war; they started out to conquer France, England and the United States because Germany wished to be the ruling power of this world. If we do not lick Germany they will lick us and take us." The thought I was trying to convey was that Germany started to conquer the world. Some place in the speech I referred to the fact that practically all of the territory Germany has she stole; by that I mean that they went out with armed force and took it, contrary to international law and treaties. This is historically true with Schleswig-Holstein country. I was making the point that in this war the United States of America is fighting the battle of the small countries of Europe. Bohemia, Denmark and all of those smaller countries

${ }^{20}$ Thomas H. Smith to Charles E. Witt [Harding's Secretary], August 2, 1918, William Lloyd Harding Papers, Sioux City Public Museum. White's judgment that the words "filth of Denmark" stung the most was surely correct, for many Iowa Danes were proud of their homeland's reputation as a cleanly dairying nation. In fact, Danish immigrants to Iowa were wont to complain that American dairymen "stopped cleaning their barns before they were finished." Author's interview with William Thompson and Jens Kierkegaard, Graettinger, Iowa, June 3, 1973. One Harlan newspaper had described Harding's speech at Sac City as "brutal in its offensiveness." Harlan Tribune, July 24, 1918. 
are vitally interested, whether allies or not, in having the United States and her allies win this war. I was also making the point that if we take the place we ought to among the nations of the world we must have a united people, and one of the best ways to accomplish this purpose is to have one language.

Anyone reading the report of the speech in the Sac City Sun [sic], which of course was less than one-third of what I actually said but a commendatory report, would gather the very impression that I have outlined. Not a soul left the meeting with the impression or the thought that an unkind thing was said about the Danes (and there wasn't), or that I had referred to their habits of living. This was not in my mind and it was not in the mind of a single soul who heard me speak." 21

Exactly what Harding said at Sac City will probably never be known. He was a renowned extemporaneous speaker and there is little to indicate that he had prepared a written text for his Independence Day speech. The Sac Sun resolutely refused to alter its original account of the governor's address; and Harding continued to deny that he had made any derogatory statements about Iowa's Danish-American citizens. ${ }^{22}$ There can be little doubt about what the Danes believed, however. Voting statistics from three heavily Danish-American precincts vividly reveal the political impact of the language issue. In the 1916 election, Harding had received $55 \%$ of the vote in the three precincts. Two years later he managed to collect less than $7 \%$ of the ballots, a drop from a total of 252 votes in 1916 to a meager 25 in $1918 !^{23}$

Despite his poor showing in the Danish precincts, Harding was able to eke out a narrow victory over Democrat Claude R. Porter on November 5, 1918, and this, along with the end of the war in Europe six days later, brought to an end the debate between the governor and Iowa's Danes over the public use of Danish. Yet the controversy had far-reaching consequences. It cer-

${ }^{21}$ Harding to Thomas H. Smith, August 12, 1918, copy in the Harding $\mathrm{Pa}$ pers, Sioux City Public Museum. Smith promptly turned the letter over to the press, see the Shelby County Republican, August 27, 1918.

${ }^{22}$ Sac Sun, August 1, 1918. An oft-told story about Harding's performances at a governor's conference in the East indicates his talent as an extemporaneous speaker. When the man scheduled to address the assembled dignitaries failed to appear, the toastmaster called upon Harding. After the Iowan had finished, the governor of Massachusetts, Calvin Coolidge, tapped Harding on the shoulder and said, "It was wonderful, Governor, I'd like to have a copy of the manuscript." "Thanks, Governor," replied Harding, "so would I." Sioux City Journal, December 18, 1934, quoted in Visser, "Harding," p. 6.

${ }^{23}$ This comparison is based on returns from Sharon and Kimballton precincts in Audubon County and Elk Horn in Shelby. Iowa Official Register, 1917-1918, pp. 564, 572; ibid., 1919-1920, pp. 455-461. 
tainly speeded the Danes' acceptance of English. In 1918, for example, Dana College, the Danish-Lutheran school at Blair, Nebraska attended by many Iowans, replaced its "Højskole," a series of high school level classes taught in Danish for new immigrants, with a "Beginner's English Course." English quickly replaced Danish in many churches, too. At a 1918 synodical convention, members of the United Danish Evangelical Lutheran Church passed a resolution requiring henceforth all men "graduating from Trinity Seminary must be able to preach acceptably in English as well as Danish." Within ten years the president of Trinity Seminary would complain that this decree was causing serious difficulties because many candidates for the ministry could no longer meet the Danish requirement. ${ }^{24}$ Ironically, the quarrel between Harding and the Danes also assisted in the demise of Elk Horn College, which had the teaching of English to Danish immigrants as its principal function.

The effect of the controversy upon Iowa politics was more immediate. As John Visser has observed in his study of Harding's public career, the language proclamation "gave his enemies an opportunity to question the character of his entire war administration." Visser believes, therefore, that the governor's poor showing in the 1918 election-he ran some 40,000 votes behind other Republicans on the ticket-may be traced to the language issue. ${ }^{25}$ Moreover, Harding's handling of the crisis, particularly as it related to the Danes, served to damage his credibility, and throughout his second term he would find it increasingly difficult to convince Iowans of his honesty.

From a political standpoint, then, the language proclamation was a mistake. No one can doubt Harding's sincerity in the matter. He was deeply concerned about the war effort and Iowa's contribution to it, but by banning all foreign languages he obviously went too far. Even George Creel, Chairman of the Wilson Administration's Committee on Public Information, believed the Iowa governor had overreacted. "Your proclamation might well have made the distinction in favor of the languages of allied and neutral countries," Creel wrote Harding, "instead of putting them all

${ }^{24}$ W. E. Christensen, Saga of the Tower, pp. 103-104, 125-126.

${ }^{25}$ Visser, "Harding," pp. 230, 244-245. 
under the ban as well as the enemy language." Many Iowans took the same view. ${ }^{26}$ But instead of acknowledging that he had erred, then modified or repealled the proclamation, Harding chose to defend it, and, in the case of the Danes at least, his actions served only to make matters worse. The clash with the Danes over the issue of language and loyalty was only one incident in a long public career, but perhaps it helps to explain why the word "controversial" is so often used to describe William Lloyd Harding.

${ }^{26}$ George Creel to Harding, September 24, 1918, Harding Papers, Sioux City Public Museum. For a good example of editorial opinion expressing the same view, see the editorial from the Red Oak Express reprinted in the Des Moines Register. June 11, 1918.

Sioux Trail, by John Upton Terrell (McGraw-Hill, 1974), tells the story of the Sioux Indians from their origins centuries ago through their days as a powerful warrior society of the Great Plains. Author Terrell bases his latest findings on archaeological, ethnological and linquistical data, offering the reader a unique and highly dramatic adventure in American history.

This book traces the Sioux from the haze of antiquity into light provided by Indian traditions, archaelogical discoveries and early historical records. 
Copyright of Annals of Iowa is the property of State of Iowa, by \& through the State Historical Society of Iowa and its content may not be copied or emailed to multiple sites or posted to a listserv without the copyright holder's express written permission. However, users may print, download, or email articles for individual use. 